\title{
That multifacet English like: how do you like it?
}

\author{
Elena A. Vikulova - Ekaterina S. Chiglintseva
}

\section{DOI: $10.18355 /$ XL.2017.10.03.29}

\begin{abstract}
The article is devoted to the English word like, its semantics and functions. It is derived from the Proto-Germanic root lik in galika 'having the same form or body'. In the course of time the meaning of physical similarity underwent such processes as semantic bleaching and subjectification, which gave rise to the development of various lexico-grammatical and pragmatic functions. It is difficult to draw clear lines of demarcation between its traditional formal functions associated with such parts of speech as conjunction, preposition, particle and its pragmatic functions, such as emphatic, hesitational, metalinguistic, examplificatory, quotative, approximative. The latter express various subjective and abstract shades of meaning. The authors analyze them with reference to pragmatics, drawing on the theories of politeness, relevance and subjectification. Most scholars define like in these pragmatic functions as 'discourse marker'; however, lexicographers refer to the word like in these discursive functions as 'adverb'. The authors carried out research into the stylistic reference of the word like in its various functions. The text analysis of Helen Fielding's Bridget Jones's Diary and the Nature journal articles has shown that the formal and pragmatic like is prevalent in the work of fiction, especially in the parts presenting conversations; it has also revealed that such uses are absent in scientific texts.

Key words: like, etymology, desemantization, pragmatic functions, discourse marker, pragmatics, subjectification.
\end{abstract}

\section{Introduction}

In Modern English it is difficult to find lexemes that can be compared to like in terms of their functional variety at the lexico-grammatical level and at the level of discourse. Dictionaries and grammars rank like among both notional parts of speech (like as a verb, noun, adjective, adverb) and functional ones (preposition, conjunction, particle). Grammaticalization, that is typical of particular lexical units, as well as the development of formal, secondary functions is an actual linguistic process, to which the English word like is an illustrative example.

Etymologically, like goes back to lic 'body' which is a shortening of $y$-lik, from Old English gelic 'like, similar,' from Proto-Germanic *galika- 'having the same form,' or literally 'with a corresponding body'. It is also a source of Old Saxon gilik, Dutch gelijk, German gleich, Gothic galeiks (Online Etymology Dictionary). Initially, physical similarity was implied and it is still preserved in the expression look like. In the course of time, however, the physical similarity expressed by the word like underwent abstraction.

In this paper the authors examine primarily formal and secondary functions of the word like which developed as a result of desemantization of the adjective like. As a functional word, like, on the one hand, performs the functions related to such functional parts of speech as preposition, conjunction, particle. On the other hand, there are communicative secondary functions, which are referred to as discursive or pragmatic in modern linguistic studies. It is important that the latter functions be described not at the level of sentence, but at the level of discourse. Their meanings must be analyzed in terms of what they indicate or mark rather than what they

XLinguae Journal, Volume 10 Issue 3, June 2017, ISSN 1337-8384 
describe. It is necessary to point out that authors of dictionaries and grammars are not always unanimous in the distinction between the functions mentioned above and in the attribution of the word like to a particular part of speech. Consequently, a practical problem arises, namely, the representation of discursive functions in learner's and other types of dictionaries: under what entry they should be listed and how exhaustive this list should be. In this paper the discussion of the aforementioned problems will be presented.

\section{Formal functions of like}

In this section we discuss the functions of like which correlate with traditional functional parts of speech. The linking function (the connection of clauses) is expressed by the conjunction like with the meanings of similarity and manner: 1) 'in the same way as' (No one sings the blues like she did) 2) = as if (spoken): She acts like she owns the place (Oxford Advanced Learner's Dictionary). Such unconventional use of like instead of as often occurs in speech, especially in American English. This substitution can be observed in the sentences of comparison as well (He treats me like I was his sister). In this case as if or as though seem to be more appropriate, because the use of like is not standard in this context. Clauses introduced by like can be frequently found, but these are often regarded as nonstandard and are typical of American English (It seems like the weather is improving) (Quirk, 1985: 1175). In other sources, e.g. The Merriam-Webster Online Dictionary the conjunction like can also be used 'interjectionally in informal speech often with the verb be to introduce a quotation, paraphrase, or thought expressed by or imputed to the subject of the verb, or with it's to report a generally held opinion' (So I'm like, "Give me a break") (The Merriam-Webster Online Dictionary).

Another formal function of the word like is the expression of a relation between two entities, one being represented by the prepositional complement, the other - by another part of the sentence. Here, like is a preposition expressing similarity: 1) She's wearing a dress like mine. 2) What's it like studying in Spain? 3) He ran like the wind (OALD). R. Quirk and his co-authors point out that the preposition like has the senses of 'resembling in appearance' and 'resembling in character'. This preposition is adjective-like in accepting the intensifier very and comparison (She looks more like $m e$ ). In some cases it can have a quasi-coordinative function (Like me she's a blonde: She's a blonde, and so am I). In comparative constructions the prepositional function of like can be interpreted as that of a conjunction. Out of hypercorrectness, as is sometimes used instead of like even as a preposition where a useful distinction should be kept between them: He spoke as a leader of mankind (in the capacity of) - He spoke like a leader of mankind (in the manner of) (Quirk, 1985: 661). This author also characterizes like as a particle, used after the verbs appear, feel, look, seem, sound, smell, taste in the adverbial clauses of manner normally introduced by as if or as though (Jill looked like / as if she had seen a ghost). Like as a particle used with the sense verb can express the speaker's attitude to the utterance, his/her subjective belief about the situation.

\section{Pragmatic functions of like}

Now we will examine the pragmatic or discursive functions of the word like. As a rule, scholars refer to like in these functions as a discourse marker. There are other terms used in literature: pragmatic marker, discourse word, discourse particle (Andersen, 1998; 2001; Brinton, 2009; Fraser, 1999; Murashkovskaya, 2014; Schiffrin, 1987). In this paper we will use the term 'discourse marker.'

Desemantization is one of the main factors that cause lexical items to develop formal and discursive functions. In the case of like the gradual transition of the adjective like into the preposition, then conjunction, and finally discourse marker was 
accompanied by generalization of meaning, semantic bleaching rather than the complete loss of it. L. Brinton considers such a process to be one of the prototypical ways of the emergence of discourse markers (Brinton, 2009: 311).

The use of like in relatively new contexts has its history. The first cases were recorded in 1778. Interestingly, the marker here is in a detached position and is put at the end of the sentence (going really fast, like). In this sentence like can be called 'postponed filler' (OED). According to G. Andersen, this construction was typical of traditional British dialects; in present-day English it can be observed in northern dialects, in the south and in London it is not prominent (Andersen, 2001: 222). In the 1950s like was used as a presumed emphatic, e.g. going, like, really fast (OED). By the end of the $20^{\text {th }}$ century another function of the discourse marker like emerged. As early as in 1982, Ronald Butters observes, in American Speech journal, a then brand new linguistic phenomenon consisting of the use of be, usually followed by like, to quote a speaker's unuttered thought, as in And he was like 'Let me say something,' or I thought I was going to drown and I was (like) 'Let me live, Lord!' (Iosef, 2013: 42). Research shows that this construction called quotative be like came from American English.

As regards the ethnicity of the speakers who use this construction, it first appeared in the speech of the US white population, in particular, in the counterculture of New York, and then it was adopted by black and Hispanic speakers (Andersen, 2001: 222). This form was more common in urban and suburban areas rather than rural areas. It was popular with teenage girls speaking so called 'Valley Girl Talk'. There is an observation that the use of be like dropped after the age of 25 and disappeared altogether by the age of 38. Many sociolinguists consider it to be characteristic of women, however, some scholars underline that it was originally used by young women, but in the course of time the gender differences disappeared (Andersen, 2001: 217). As G. Andersen concludes, the construction be like is an Americanism that has spread to Britain as a result of extensive cross-cultural contact on large scale.

E.M. Murashkovskaya distinguishes between two levels of the discourse marker like functioning: the level of text and the interpersonal level. On the level of text the word like can function as a filler (hesitation device). This usage occurs in the situations where the speaker wants to formulate his thoughts more accurately and tries to gain time. Another function on the level of text is connected with a false start, when the speaker has already started expressing himself but then decides to put it in another way. Furthermore, the word like can serve to emphasize what follows, the thing being important in the speaker's opinion. It can also serve as a downtoner or mitigating device to make the statement less strong or categorical. It can also be used in order to start a new topic or to present new/additional information. As far as the interpersonal level is concerned, the discourse marker like can be used to comment on the information presented, to express understanding or incomprehension, affection and other feelings, as well as to clarify the information (Murashkovskaya, 2014: 118-120).

A similar classification of the discursive functions of like based on corpus data was proposed by G. Andersen. Apart from the previously mentioned functions connected with a false start, a slip of the tongue and the introduction of new information G. Andersen distinguishes the following pragmatic functions in the speech of middle-aged people: examplificatory (It wouldn't be any point if someone wanted to be, like, a doctor and they got into a nursery place); approximative (My lowest ever was like forty); hesitational and metalinguistic use of like (The conversation between two teenagers: It's like not moral. - Not [laughing] moral). In the last example like expresses the attitude of the speaker to the utterance and serves 
as a signal that the chosen word is not typical of his speech. The speaker feels discomfort and the marker like allows him to distance himself from it. Not moral is a bit pompous and is not fully internalized in the vocabulary, that is why the speaker uses like. The other speaker repeats not moral laughing and proves the inappropriate character of the words.

Another important discursive function is the introduction of direct speech, the speaker's thoughts, somebody else's words e.g. And then I'm like 'No Way!' In sentences of this kind the relation between a linguistically encoded concept and the concept that is in the speaker's thoughts is one of non-identical resemblance. Like is a signal of a thought/utterance discrepancy. The speaker interprets somebody's words. This interpretation can be a literal rendering, less than literal (loose) rendering or just a general impression. The utterance is similar semantically and logically to what the speaker interprets. As the verb be quite often precedes like, it can be called a set expression 'quotative like' or 'be like quotative complementiser'. It is synonymous to the verbs say or think, but what follows like is not necessarily the representation of an uttered thought, internal speech can also be introduced with the help of this marker (Andersen, 2001: 217).

\section{Like in terms of pragmatics}

Recently, extensive research into discourse markers has been based on such pragmatic theories as the relevance theory, politeness theory and the theory of (inter)subjectification. In this section we will attempt to show how these theories highlight the functions of like. Despite all the versatility of the described pragmatic functions, the common feature is that the word like in all the cases gives more relevance to the utterance. The search for relevance is a basic feature of human cognition. In the framework of relevance theory put forward by D. Sperber and D. Wilson, the utterance is 'relevant to the individual when it connects to background information to yield conclusions that matter to him: say, by answering a question he had in mind, improving his knowledge on a certain topic, settling a doubt, confirming a suspicion, or correcting a mistaken impression. According to the relevance theory, an input is relevant to an individual when its processing in a context of available assumptions yields a positive cognitive effect. A positive cognitive effect is a worthwhile difference to the individual's representation of the world: a true conclusion, for example. False conclusions are not worth having; they are cognitive effects, but not positive ones.' It is stated that the greater the processing effort required, the less relevant the input will be. The less processing effort is required, the more relevant the utterance will be (Wilson, Sperber, 2006: 608-609). G. Andersen argues that the discourse marker like helps the listener to get a positive cognitive effect without much processing effort. Non-literalness of the utterance, loose interpretation signaled by the use of like facilitates the process of understanding. The speakers are engaged in the so called 'loose talk' (Andersen, 1998: 154 - 155).

The discourse marker like is one of the means of the negative politeness strategy used to achieve non-categorical character of the utterance, to distance yourself from it, not to impose yourself, avoid conflicts, respect the interlocutor. All these strategies are considered to be typical of English culture (Brown, Levinson, 1987: 129 - 130).

Another common feature of all the discursive functions of like is that they are focused on the speaker and serve the procedural purposes of expressing speaker's attitude to the utterance. The language structures' ability 'to provide for the locutionary agent's expression of himself and his own attitudes and beliefs' is called subjectivity (Traugott, 2003: 125). The distinction needs to be made between subjectivity and intersubjectivity. The latter marks not the speaker's attitude or viewpoint but the speaker's attention to the addressee's self-image or face. The two notions belong to the synchronic state. The diachronic processes of developing the 
(inter)subjective senses of lexemes are called subjectification and intersubjectification (Traugott, 2003). Discourse markers are among these lexemes. The notional word like began to be used in the textual domain to connect clauses and later in the interpersonal domain to serve as a hedge or mitigating device when there are constraints on the interaction between the speaker and his interlocutor and the speaker needs to soften the impact of an utterance or distance himself/herself from it. Such uses of discourse markers are also consistent with the Cooperative principle proposed by Paul Grice in that they make utterances relevant, informative, and brief; they help to avoid saying something for which you lack adequate evidence (Grice, 1975: 46-47).

\section{Like in fiction and scientific texts}

Taking into consideration functional peculiarities of like, described in linguistic literature, we carried out research into lexico-grammatical, stylistic and communicative aspects of this phenomenon. The material was collected from the novel Bridget Jones's Diary by Helen Fielding and the scientific journal Nature (300,000 characters). We restricted our research to like as a conjunction, preposition and discourse marker, as the analysis of their distribution in two contrastive functional styles seems interesting in terms of identifying dominant trends in Modern English.

The text of fiction gave 187 instances of the lexeme like in the functions under discussion. Most of them (169) represent the preposition (1). Like as a conjunction appeared in 8 sentences (2):

(1) There we were, just him and me, caught in a massive electrical-charge field, pulled together irresistibly, like a pair of magnets (Fielding, 2001: 58)

(2) 'Um, I don't know. I was bringing the phone into the other room like I said,' I said. (Fielding, 2001: 163)

Frequent use of the preposition like in this work of fiction is consistent with the genre and characters of the novel. The author's text (internal speech) and the speech of the characters abound with syntactic constructions expressing the comparison of objects, people, phenomena and meanings, their correlation. As a rule, identification, equality or complete similarity of the facts, described in the noveldiary, do not need to be established.

As for the discourse marker like, it appeared in 10 sentences. The following are some of the examples:

(3) Gav was staring at me. 'Wow, that is, like, a really, really, really wild ... ' he whispered reverently as I blinked back tears, '.... response.' (Fielding, 2001: 193)

(4) 'Come and talk to Gav,' he said. 'He's really, like, into you.' Then he took one look at my face and said. 'Oh shit, I'll take you home.' (Fielding, 2001: 193)

Let us analyze (3). The utterance belongs to Gav, a 22-year-old young man. The main character Bridget Jones was on the verge of tears. Gav was taken aback by her reaction. He compares in his mind what he wants to express and the actual wording that he uses. He realizes that the words 'wild response' do not fully correspond to what he wants to express. The word like is used here as a filler as well as a hedge. The speaker is hesitant and is trying to choose the words carefully and fills in a pause. What is more, he wants to distance himself from what he is saying and mitigate the effects of his utterance in order not to offend the listener because he does not know her well and their conversation takes place in a semi-formal atmosphere (at the Saatchi Gallery). The marker like here, as in many other examples, shows the

XLinguae Journal, Volume 10 Issue 3, June 2017, ISSN 1337-8384 
speaker's personal attitude to the utterance. The semantic meaning of similarity is present here, but it is much more abstract and bleached than in the case of the conjunction or preposition like.

In (4) the utterance belongs to Daniel, Bridget's friend. The discourse marker like serves as a filler and a form concealing hesitation. In this situation Daniel is trying to choose the right words to calm Bridget. The expression 'really into you' does not exactly represent what Daniel thinks of Gav and his attitude to the main character. What is more, Daniel thinks that the phrase 'really into you' will be quite relevant and will spare him the trouble of going into detail. can be observed.

In the other 8 examples the metalinguistic, emphatic, hesitational functions

Overall, the sentences containing the discourse marker like make $5 \%$ of the whole body. That is not much, but representative when taking into account some sociolinguistic and extralinguistic factors. First of all, the main character of the novel is a woman in her thirties, and she is surrounded by people of the same age. As research shows, the use of the discourse marker like is a characteristic feature of teenagers and young people under 30. Secondly, the novel was published in 1996, at that time this marker was a relatively new phenomenon. The use of like in various pragmatic functions was initially observed in the USA and in the course of time it appeared in British English. The novel was written by a British writer and it is set in England.

In order to analyze the distribution of like in two functional styles, we collected data from the Nature journal as well. In the body of exclusively scientific texts only 15 instances of the word like in functions under discussion were found, 14 of them being prepositions and 1 being a conjunction. The fact that like in its formal and discursive functions expresses abstract similarity and correspondence makes its use in the scientific texts unlikely, because the expression of identification, complete similarity, and equality has a higher priority with them. The instances found belong to quotations, interview fragments and the like (5). The only example of the conjunction like is represented by direct speech (6).

(5) 'Like me', he adds, 'hundreds of other scientists had their careers advanced using WI-38 and other human cell cultures so we all owe a moral debt to the tissue donors' (Nature, 2013: 426).

(6) But, says Charo, if we continue to debate it entirely in legal terms, it feels like we're missing the emotional centre of the story' (Nature, 2013: 426).

In this research we prove the status of formal and discursive functions as spoken, pertaining to the colloquial speech.

\section{Classification models and lexicographic description.}

As stated above, the word like is highly versatile and the problem of the classification and lexicographic description of its functions remains unsolved. The term 'discourse marker' is used with reference to the class of lexical items which regulate and organize the process of communication. These functions are considered to be secondary in relation to the primary one - the function of expressing propositional content of syntactic structure. The principal difference between grammatical and communicative aspects of the sentence allows us to use the method of cross classification, when groups based on one feature are then subdivided based on other characteristic features. E. Viktorova claims that the incorporation of words into the class of discourse markers has transcategorical character and may include particles, interjections, conjunctions, nouns, verbs, adjectives, adverbs (Viktorova, 2014: 18). As regards like, it is emphasized that in its communicative functions this 
word does not belong to traditional connectors such as prepositions and conjunctions, it corresponds more to interjections (Siegel, 2002: 38).

Speaking about the problem of the lack of classification model for communicative functions, it is necessary to point out that in English-English dictionaries all the discursive functions of the word like are listed under the entry adverb. This practice is based on the functional properties of this class of words, namely, the expression of adverbial background information as opposed to the propositional content. The English adverbial as a syntactic category is represented by the subclasses of adjuncts, disjuncts and conjuncts. The difference between them is that the first class is integrated in the sentence structure, while the second and third, as a rule, are on the periphery of the sentence and have a detached position. The detached conjuncts are said to perform the connective function at the text level (Quirk, 1976: 208). This syntactic function corresponds to what the discourse marker like expresses in general, but a detailed classification is also necessary. Quite often the dictionary entry contains comments such as 'used to intensify, emphasize, underline'. Popular learner's dictionary 'Longman Dictionary of Contemporary English' lists two discursive functions: 1 ) used in speech to fill a pause while you are thinking what to say next 2) I'm/he's/she's like ... (used to tell the exact words someone used; used to describe an event, feeling, or person, when it is difficult to describe or when you use a noise instead of words) (Longman Dictionary of Contemporary English). English-English Learner's dictionaries are more detailed in such descriptions than Russian dictionaries. For instance, one of the most popular bilingual Russian dictionaries compiled by V. K. Mueller gives a vague translation 'так сказать, как бы' (so to say, kind of) and marks this usage as spoken (Mueller, 2013: 501). The necessity and importance of listing and structuring discursive functions in dictionaries are evident. These functions play an important part in communication, as well as in the process of teaching and learning a foreign language. Lexicographic model for the description of discourse markers as a separate class of words is currently being developed. (Shilikhina, 2015: 120). The method of cross classification seems appropriate as their attribution to this or that part of speech is not a dominant feature in communicative aspect, however, technical aspects of this problem are in the domain of lexicography.

\section{Conclusion}

The English word like in the process of its functional development has acquired characteristic features of an operator - a discourse marker, expressing subjective shades of meaning important for the speaker. This communicative process is to be continued as the abstract semantic meaning of similarity of the lexeme like promotes its use in various pragmatically conditioned contexts, primarily, colloquial. Contextual variety and the absence of classification models make difficult the description of these discursive functions as well as their listing in dictionaries based on traditional models. Research in this field can be further continued using theories and methods of pragmatics, in particular, the relevance and politeness theories as well as the theory of subjectification.

\section{Bibliographic references}

ANDERSEN, G. 1998. The Pragmatic Marker like from a Relevance-theoretic Perspective. In: Discourse Markers: Descriptions and Theory. Ed. by Andreas H. Jucker and Yael Ziv John Benjamins B.V, pp. 147-170. ISBN 9781556198205. 
ANDERSEN, G. 2001. Pragmatic Markers and Sociolinguistic Variation: A Relevance-theoretic Approach to the Language of Adolescents. Amsterdam: John Benjamins Publishing. 352 p. ISBN 9781588110183.

BRINTON, L. 2009. Pathways in the Development of Pragmatic Markers in English. In: The Handbook of the History of English. Ed. by Ans van Kemenade and Bettelou Los. Blackwell Publishing Ltd., pp. 307-334. ISBN 9781405187862.

BROWN, P. - LEVINSON, S. 1987. Politeness: Some Universals in Language Usage. Cambridge University Press. 345 p. ISBN 9780000011817.

FIELDING, H. 2001. Bridget Jones's Diary. London: Picador. 310 p. ISBN 9780330375252.

FRASER, B. 1999. What are discourse markers? In: Journal of Pragmatics, vol. 31, pp. 931-952.

GRICE, H.P. 1975. Logic and Conversation. In: Syntax and Semantics, vol. 3, Speech Acts, Ed. by Peter Cole and Jerry L. Morgan. New York: Academic Press, pp. 41-58. ISBN 978-0127854236.

IOSEF, M. 2013. Signs of Colloquialization. Three Corpus-Based Case Studies (master's thesis).Oslo University. 139 p.

LDCE - Longman Dictionary of Contemporary English [Electronic resource]. URL: http://www.ldoceonline.com

MUELLER, V. K. 2013. Polnyi anglo-russkii russko-angliiskii slovar'. 300000 slov i vyrazhenii. Moscow: Izdatelstvo: Eksmo. 1327 p. ISBN 9785699562985.

MURASHKOVSKAIA, E. M. 2014. Diskursivnyi marker like v molodezhnom onlain-diskurse. In: Vestnik ChGPU im. I.Ia Iakovleva, vol. 82, pp. 116-121.

MWOD - The Merriam-Webster Online Dictionary [Electronic resource]. URL: http://www.merriam-webster.com

Nature. 2013. Vol. 498. No. 7455. Nature Publishing Group. ISSN 0028-0836.

OALD - Oxford Advanced Learner's Dictionary [Electronic resource]. URL: http://www.oxfordlearnersdictionaries.com

OED - Online Etymology Dictionary [Electronic resource]. URL: http://www.etymonline.com

QUIRK, R. - GREENBAUM, S. 1976. A University Grammar of English. Longman. 484 p. ISBN 978-0582552074.

QUIRK, R. 1985. A Comprehensive Grammar of the English Language. Longman Group Limited. 1779 p. ISBN 0582517346.

SCHIFFRIN, D. 1987. Discourse Markers. Cambridge: Cambridge University Press. 364 p. ISBN 9780511611841.

SHILIKHINA, K. M. 2015. Izuchenie diskursivnykh markerov metodami korpusnoi lingvistiki. In: Vestnik VGU. Seriia: Lingvistika i mezhkul'turnaia kommunikatsiia, vol. 3, pp. 120-125.

SIEGEL, M. 2002. Like: The Discourse Particle and Semantics. In: Journal of Semantics, vol. 19, pp. 35-71.

TRAUGOTT, E. C. 2003. From Subjectification to Intersubjectification. In: Motives for Language Change. Ed. by R. Hickey. Cambridge University Press, pp. 124-142. ISBN 9780511486937.

VIKTOROVA, E. Iu. 2014. Pragmaticheskaia polifunktsional'nost' diskursivnykh slov. In: Vestnik VGU. Seriia: Lingvistika i mezhkul'turnaia kommunikatsiia, vol. 2, pp. 18-22.

WILSON, D. - SPERBER, D. 2006. Relevance Theory. In: The Handbook of Pragmatics. Ed. by Laurence R. Horn and Gregory Ward. Blackwell Publishing Ltd., pp.607 - 632. ISBN 9780631225485. 
Words: 4636

Characters: 24967 (13.87 standard pages)

assoc. prof. PhD. Elena A. Vikulova

Department of Germanic Philology

Ural Federal University

51, Lenin Ave.

Yekaterinburg, Russia

vilena48@bk.ru

Ekaterina S. Chiglintseva

Department of Germanic Philology

Ural Federal University

51, Lenin Ave.

Yekaterinburg, Russia

ekaterina.ch@bk.ru 